\title{
THE FLORA OF TOWNSHIP LAGOON NATURE RESERVE AND ITS MANAGEMENT, TUNBRIDGE, TASMANIA
}

\author{
by Andrew Zacharek, L. Gilfedder and S. Harris \\ (with four tables, four text-figures, two plates and an appendix)
}

\begin{abstract}
Zacharek, A.R., Gilfedder, L. \& Harris, S., 1997 (31:viii): The flora of Township Lagoon Nature Reserve and its management, Tunbridge, Tasmania. Pap. Proc. R. Soc. Tasm. 131: 57-66. https://doi.org/10.26749/rstpp.131.57

ISSN 0800-4703. Department of Geography and Environmental Srudies, University of Tasmania, GPO Box 252-78, Hobart 7001 (AZ); Parks and Wildlife Service, Department of Environment and Land Management, GPO Box A, Hobart 7001 (SH, LG), formerly Department of Geography and Environmental Studies (LG).
\end{abstract}

Township Lagoon Nature Reserve is 16 ha of remnant native grassland in the lowest rainfall area of Tasmania. A high proportion of rare and threatened species occurs within the reserve. They comprise four endangered species, including rhree endangered at the national level, four vulnerable species and eight rare species, seven of the above being daisies. There is a strong floristic affinity with the semi-arid mallee ground flora in northwestern Victoria and western New South Wales. The small grassland remnant comprises five floristic communities, the principal influences on floristic variation being exerted by soil factors, such as geology, $\mathrm{pH}$ and drainage, and past history of mechanical disturbance and rubbish dumping. Active conservation management, that is favourable to the continued existence of vulnerable and rare species, promotes normal ecosystem functions and prevents threatening processes, is essential.

Key Words: vegetation, nature reserve, salt lake, weeds, rare and threatened plants, low rainfall flora, Tasmania.

\section{INTRODUCTION}

Township Lagoon Nature Reserve at Tunbridge in the southern Tasmanian Midlands, is a native grassland and grassy woodland remnant dominated mainly by kangaroo grass (Themeda triandra). An early painting of the Salt Pan Plains by Joseph Lycett indicates that the pre-European vegetation of the area was a treeless grassy plain (Fensham 1989). Township Lagoon Nature Reserve is listed on the Register of the National Estate and also protects one of only four natural salt lakes that occur in Tasmania. Natural grasslands and grassy woodlands were once extensive in the lowlands of the Midlands, but today the natural vegetation has been dramatically altered, with only $13 \%$ of the vegetation resembling the original remaining and virtually all of this privately owned (e.g. Fensham \& Kirkpatrick 1989, Gilfedder $\&$ Kirkpatrick 1995b). The Midlands were arguably the birthplace of the agricultural and pastoral industries in Australia. In Tasmania, grasslands and grassy woodlands are the most threatened vegetation type, with 22 of the 37 communities described for Tasmania being unprotected in any national park or state reserve (Kirkpatrick et al. 1988). There is a high concentration of rare and threatened plant taxa in the Midlands (Kirkpatrick et al. 1988, Gilfedder 1990), including many species that are not protected in any other state reserve (Kirkpatrick et al. 1991a, b). The reserve has been recognised as an important grassland remnant (Kirkpatrick et al. 1988; Kirkpatrick et al. 1991a). It is an important locality for the glossy tussock lizard Pseudemoia pagenstecheri (Rounsevell et al. 1996), the isopod, Haloniscus searlei (Fulton 1976) and a recently rediscovered moth (Chrysolarentia decisaria) and rare grasshopper (Brachyxema lobipennis) (P. McQuillan, pers. comm.). The area is an important faunal refuge for rare invertebrates. Two crustaceans recorded from salinewaters on mainland Australia have their only known Tasmanian occurrences at Township Lagoon (Fulton 1976). They are the isopod Haloniscus searlei Chilton and the ostracod Australocypris robusta De Deckker. The water fleas Diacypris sp. nova and Calamoecia clitellata Bayly also occur at Township Lagoon (Buckney \& Tyler 1976).

The aims of this study are to produce an inventory of the flora, to describe the vegetation communities, to gain understanding of the environmental factors, including the role of fire, and to make preliminary recommendations on management of the reserve.

\section{MATERIALS AND METHODS}

\section{The Study Area}

Township Lagoon Nature Reserve (fig. 1; pls 1, 2)is an area of approximately 16 ha which was set aside for the expansion of the town of Tunbridge and remained unallocated crown land until the mid-1980s, when its conservation significance was recognised. The area was proclaimed as a Nature Reserve on 25 December 1991.

The climate of the Tunbridge district is dry subhumid cool (Gentilli 1972), characterised by a long warm season and peak rainfall in the spring and autumn. This is one of the lowest rainfall areas in the state, with a mean annual rainfall of $462 \mathrm{~mm}$ per annum (table 1). The mean daily minimum temperature for the coldest month is $1.1^{\circ} \mathrm{C}$; the mean daily maximum temperature for the warmest month is $22.6^{\circ} \mathrm{C}$ (table 1). Annual rainfall for $1990-92$ and $1994-$ 96 has been, on average, $430 \mathrm{~mm}$, which is $93 \%$ of the long-term average, indicating the unreliability of rainfall (fig. 2).

The reserve is underlain by Tertiary basalt in the elevated areas of the reserve. The basalt overlies Triassic sediments which crop out in the lower areas around and to the east of the lagoon. The site is at approximately 200-240 m elevation. The soils consist of clay and very dark-brown to black, duplex clay loam, and are fertile, with moderate to high permeability (Davies 1988).

The reserve was leased for stock-grazing until the $1960 \mathrm{~s}$ and is at present irregularly and lightly grazed. Patches of 


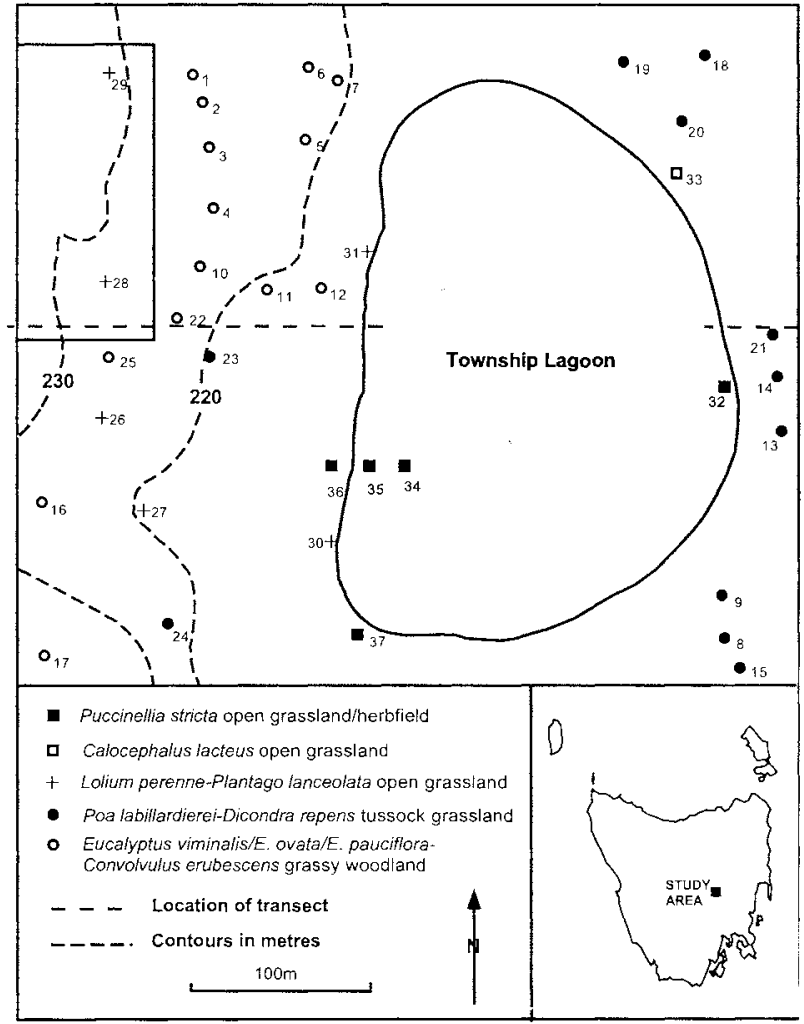

FIG. I - Township Lagoon Nature Reserve at Tunbridge in the Midlands of Tasmania ( $\left.42^{\circ} 8^{\prime} \mathrm{S}, 147^{\circ} 15^{\prime} \mathrm{E}\right)$.

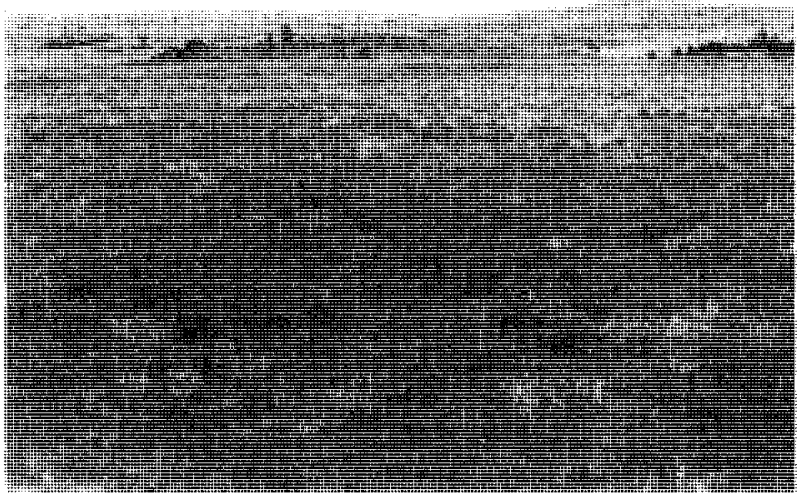

PLATE I

View looking south with Themeda triandra grassland with abundant flowering heads of Chrysocephalum apiculatum at Township Lagoon Nature Reserve, Tunbridge (Dec. 1991). Photo: A. Zacharek.
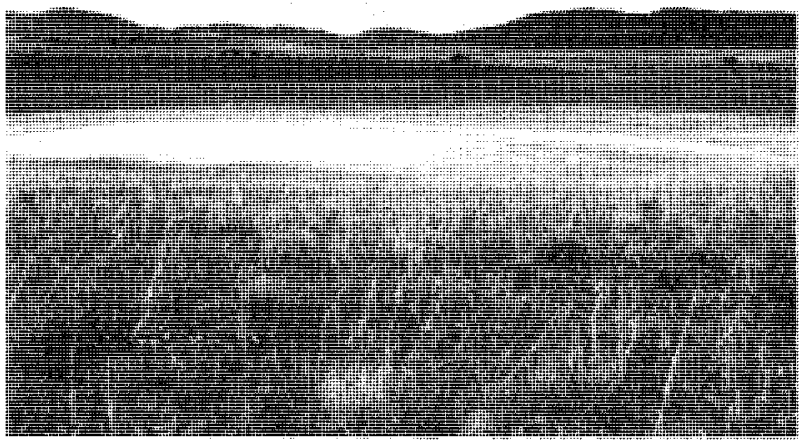

PLATE 2

Looking east toward Township Lagoon across Themeda triandra grassland (Dec. 1991). Photo: A. Zacharek.
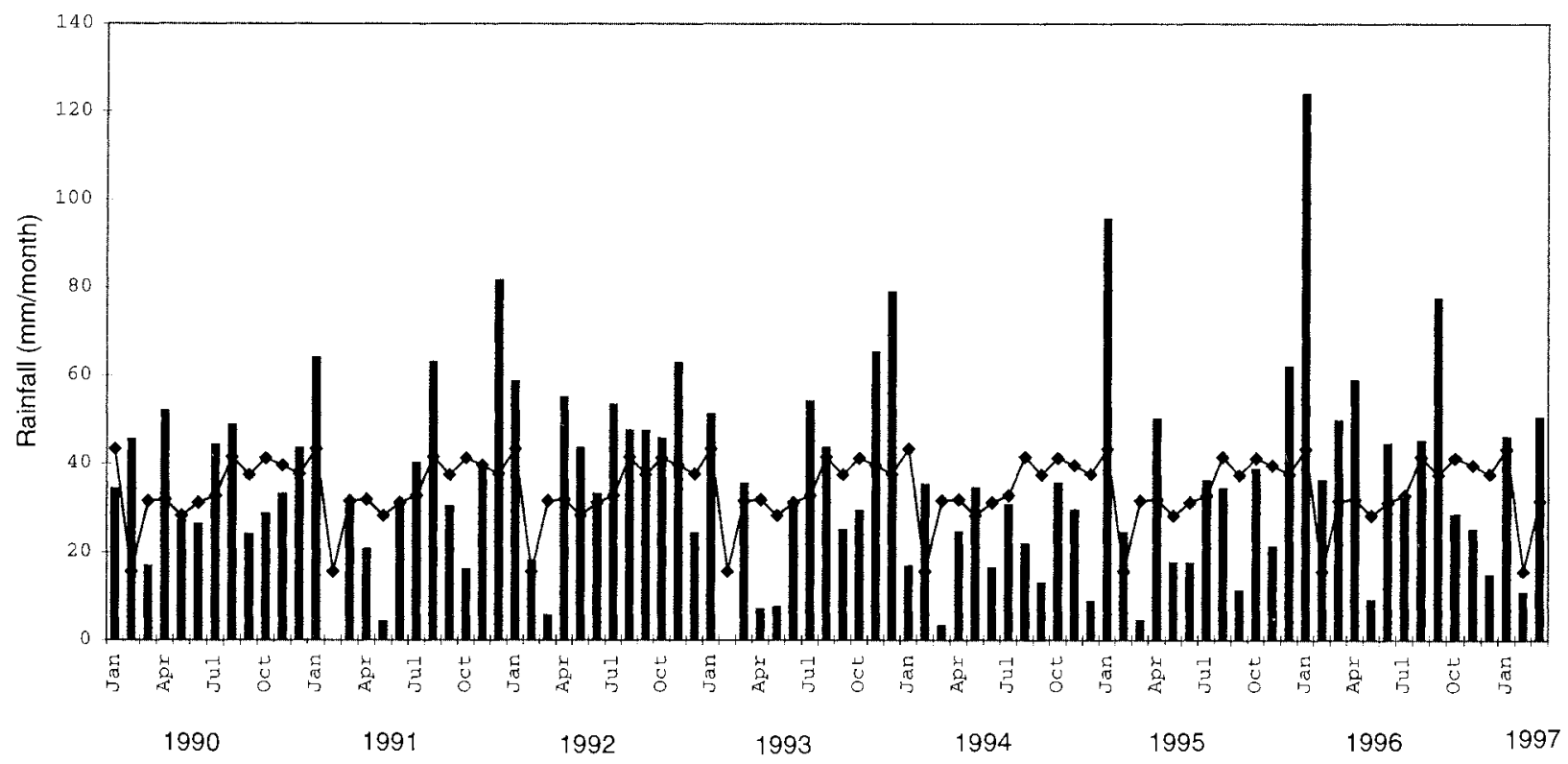

FIG. 2 - Mean monthly rainfall at Tunbridge, 1990-March 1997; the long-term monthly average is calculated from Bureau of Meteorology data covering the period 1972-97. Annual precipitation totals were $443 \mathrm{~mm}(1990), 421 \mathrm{~mm}(1991), 494 \mathrm{~mm}$ (1992), $270 \mathrm{~mm}$ (1994), $413 \mathrm{~mm}$ (1995) and $545 \mathrm{~mm}$ (1996); the 1993 data is incomplete. Monthly precipitation is indicated by bars and the line indicates the long-term monthly average. 
TABLE 1

Summary of precipitation and rain days for Tunbridge* and temperature data for Ross ${ }^{\dagger}$

\begin{tabular}{|c|c|c|c|c|c|c|c|c|c|c|c|c|c|}
\hline & Jan & Feb & Mar & Apr & May & Jun & Jul & Aug & Sep & Oct & Nov & Dec & $\begin{array}{r}\text { Annual } \\
\text { total }\end{array}$ \\
\hline \multicolumn{14}{|c|}{ Tunbridge* total monthly precipitation } \\
\hline Mean & 43.3 & 19.5 & 33.4 & 39.3 & 37.2 & 32.9 & 41.0 & 40.7 & 39.3 & 40.8 & 44.2 & 44.4 & 461.5 \\
\hline Highest & 124 & 62.0 & 75.2 & 94.6 & 92.0 & 76.0 & 103.6 & 83.8 & 116.6 & 73.6 & 110.8 & 140.2 & 633.5 \\
\hline Lowest & 4.8 & 0.0 & 3.2 & 5.6 & 4.2 & 11.2 & 11.4 & 3.8 & 9.6 & 13.0 & 7.6 & 6.0 & 269.6 \\
\hline Number & 24 & 23 & 24 & 23 & 23 & 24 & 24 & 24 & 25 & 25 & 25 & 25 & 22 \\
\hline \multicolumn{14}{|l|}{ Tunbridge ${ }^{*}$ raindays } \\
\hline Mean & 7.8 & 5.0 & 7.5 & 9.5 & 10.4 & 11.5 & 12.9 & 13.0 & 11.5 & 10.9 & 10.3 & 9.3 & 119.8 \\
\hline Highest & 12 & 11 & 12 & 17 & 16 & 14 & 20 & 20 & 19 & 22 & 16 & 23 & 138 \\
\hline Lowest & 4 & 0 & 2 & 4 & 5 & 8 & 7 & 3 & 2 & 5 & 4 & 2 & 95 \\
\hline Number & 24 & 23 & 24 & 23 & 23 & 24 & 24 & 24 & 25 & 25 & 24 & 25 & 22 \\
\hline \multicolumn{14}{|c|}{ Ross $s^{\dagger}$, summary of daily temperature } \\
\hline Mean daily max. temp. & 22.6 & 22.1 & 20.3 & 16.1 & 13.7 & 10.9 & 10.5 & 11.9 & 13.0 & 16.7 & 18.2 & 21.7 & 16.5 \\
\hline Highest temp. & 34.6 & 34.0 & 28.8 & 23.2 & 18.7 & 15.8 & 15.7 & 18.0 & 19.7 & 28.8 & 26.6 & 33.9 & 34.6 \\
\hline Lowest Max. temp. & 14.4 & 13.1 & 12.6 & 9.9 & 8.7 & 5.7 & 4.3 & 7.9 & 7.7 & 10.1 & 10.4 & 13.4 & 4.3 \\
\hline Mean daily min. temp. & 10.2 & 10.1 & 7.1 & 5.6 & 2.7 & 1.5 & 1.1 & 2.3 & 2.5 & 4.9 & 6.1 & 8.0 & 5.2 \\
\hline Highest min temp. & 18.9 & 18.9 & 14.8 & 15.8 & 12.1 & 12.5 & 9.6 & 10.0 & 10.2 & 12.4 & 12.9 & 17.2 & 18.9 \\
\hline Lowest temp. & 0.5 & 1.5 & -1.6 & -4.3 & -5.9 & -6.6 & -6.2 & -5.8 & -4.2 & -3.2 & -1.5 & -2.5 & -6.6 \\
\hline
\end{tabular}

* Cheam ( $\left.42^{\circ} 07^{\prime} \mathrm{S}, 147^{\circ} 21^{\prime} \mathrm{E}\right)$, elevation $220 \mathrm{~m}$; available data $1972-97$.

† $42^{\circ} 02^{\prime} \mathrm{S}, 147^{\circ} 30^{\prime} \mathrm{E}$, elevation $195 \mathrm{~m}$; data $1993-97$.

native grassland and grassy woodland in paddocks adjacent and to the west, south and north of the reserve are contiguous with the grasslands of the nature reserve. In particular, on a hill on adjacent private land to the west of the reserve, grassy woodland dominated by Eucalyptus pauciflora occurs. Approximately half of the land adjacent to the reserve has been sown to improved pastures or crops.

In the northwestern corner of the block an area of 1 ha is fenced off and currently used as a refuse disposal site but, in the past, more extensive areas were used, and sporadic rubbish dumping in the reserve still occasionally occurs. In addition, along the edges of the block, public rights of way exist, and these are used for access to adjacent land. Driving of vehicles on the native vegetation and on the dry lagoon bed is common.

The reserve is irregularly burned, when fires escape from the rubbish tip. In 1987, a fire burnt most of the area to the west of the lagoon. In December 1993, patches of the grassy vegetation to the west of the lake were subject to a planned burn but, in September 1994, a large proportion of the remaining area was burned by a fire of unknown origin.

\section{Vegetation Sampling}

Thirty-seven quadrats were located in a subjective without preconceived bias manner (Mueller-Dombois \& Ellenberg 1974) in the reserve. Each quadrat measured $10 \times 1 \mathrm{~m}$, and all vascular plant species were recorded, both in November 1991 and in January 1992, to maximise the chances of positive identification of species. Authorities for species nomenclature follow Buchanan (1995). Slope and aspect were recorded, using a clinometer and a compass respectively. Soil pH was determined for each quadrat, using a CSIRO soil-testing kit.

The polythetic divisive classification program TWINSPAN (Hill 1979) was used to help sort the $10 \times 1 \mathrm{~m}$ quadrat data into floristic groups, using the presence of native species only. With the $10 \times 1 \mathrm{~m}$ quadrats, two groups were separated on the second division of TWINSPAN, one on the third, and two on the fourth levels. Four quadrats were manually reassigned. The frequencies of species in the quadrats of the floristic groups were calculated. The floristic groups that corresponded most closely to the plant communities of Kirkpatrick et al. (1988) were determined.

A transect line, running orthogonal to the slope (fig. 1.), was placed across the nature reserve and into the adjacent native pasture on private land, and was surveyed, using a tape and dumpy-level. Forty-four $1 \times 1 \mathrm{~m}$ quadrats were located along the transect, at $10 \mathrm{~m}$ intervals, with an estimate of the percentage cover of all higher plant species, the combined cover for native and exotic grasses and forbs, and bare ground (Mueller-Dombois \& Ellenberg 1974). Native, exotic and total plant species richness per plot were determined.

Soil samples from the transect were weighed after airdrying overnight. The samples were then dried in an oven at $105^{\circ} \mathrm{C}$ for $30 \mathrm{~min}$. to determine soil moisture (Rayment \& Higginson 1992). Organic matter was then escimated as loss on ignition by heating the soil samples at $550^{\circ} \mathrm{C}$ for one hour.

\section{Burning Experiment}

The effects of an unplanned fire on the Themeda triandra tussock grassland ar Township Lagoon were monitored for 27 months to determine how quickly the above-ground 
biomass recovered, and to monitor any short-term changes in the species composition of the area. Twenty $0.25 \mathrm{x}$ $0.25 \mathrm{~m}$ quadrats were randomly located over the area at each harvest and the above-ground biomass was removed (biomass in this context is taken as the net primary acrial production of the grassland) and sorted into component parts. Dry weight was determined following oven drying at $105^{\circ} \mathrm{C}$ for 24 hours. The biomass was harvested at regular intervals to coincide approximately with the peak of the growing season and the end of the growing season. The study area was burned in mid-October 1986, and harvests were made at three weeks (6 November 1986), 8.5 weeks (17 December 1986), 13 weeks (17 January 1987), 55 weeks ( 10 November 1987), 69 weeks (20 February 1988) and 117 weeks (24 January 1989). Floristic data were available for the study area prior to the fire, and quadrat data were collected postfire, so that comparisons were possible.

\section{RESULTS}

The reserve has a high plant community diversity, ranging from a distinct assemblage of saltmarsh species on the shores of the saltlake, Poa tussock grassland to Themeda triandra grassland and grassy woodland, and is also an area of high native plant species richness, considering its small area (16 ha). The 114 native species found in Township Lagoon Nature Reserve represent approximately 15\% of the 750 native plant species of grasslands in Tasmania (Kirkpatrick 1994), while the 75 exotic species present comprise $14 \%$ of the total exotic species in Tasmania (table 2 ). There is a very high concentration of endangered, vulnerable and rare species, as listed in Schedules 3 to 5 of the Threatened Species Protection Act 1995 (Tasmania). There are four endangered, four vulnerable and eight rare species, and of the four endangered species, three are endangered nationally (table 3). The full list of species found in the reserve is given in appendix 1 .

\section{Plant communities}

The vegetation is best represented by five floristic groups; these are listed below, with plant species that were found in at least $40 \%$ of the quadrats. In some cases, species which were characteristic of a community but were sporadic in occurrence are included. The soil types and $\mathrm{pH}$ and species richness for the floristic groups are listed in table 4.

The floristic groups are as follows (numbers of quadrats in the groups in parentheses):

Flo: stic Group 1 Puccinellia stricta open grassland/herbfield $(\mathrm{n}=5)$

Native graminoids: Puccinellia stricta

Native forbs: Apium prostratum, Spergularia media, Isolepis sp., Selliera radicans

Exotic graminoids: Hordeum marinum

Exotic forbs: Plantago coronopus, Leontodon taraxacoides

The vegetation comprises very prostrate, succulent species and exotic rosette herbs near the lake edge, with orher species away from the lake in areas of low relief that may be affected by winds blowing across the lake. There was a high percentage of bare ground, and the soils have heavy black clay A horizons ( $\mathrm{pH}$ 9) over brown clay B horizons that overlay sandstone.
TABLE 2

Number of plant species and categories recorded at Tunbridge Township Lagoon Nature Reserve

\begin{tabular}{lcc}
\hline Category* & Number & \% of total \\
\hline Total species & 189 & 100 \\
Native species & 114 & 60 \\
Introduced species & 75 & 40 \\
Endemic species & 6 & 3.2 \\
Endangered & 4 & 2.1 \\
Vulnerable & 4 & 2.1 \\
Rare & 8 & 4.2 \\
Dicotyledons & 126 & 67 \\
Monocotyledons & 62 & 33 \\
Ferns & 1 & $<1$ \\
\hline
\end{tabular}

* Conservation status is according to Schedules 3 to 5 of the Threatened Species Protection Act 1995 (Tasmania).

TABLE 3

List of vascular plant species endangered, vulnerable or rare in Tasmania*

Taxa of flora which are endangered

ASTERACEAE

Leucochrysum albicans (A. Cunn.) Paul G. Wilson subsp.

albicans var. tricolor (DC.) Paul G. Wilson (Hoary Sunray) (E)

BRASSICACEAE

Lepidium hyssopifolium Desv. (Peppercress) (E)

RANUNCULACEAE

Ranunculus prasinus Menadue (Tunbridge Buttercup) (E, EN) STACKHOUSIACEAE

Stackhousia gunnii Hook.f. (Gunn's Mignonette) (EN)

Taxa of flora which are vulnerable

ASTERACEAE

Brachyscome rigidula (DC.) G.Davis (Hairy Cutleaf Daisy)

CARYOPHYLLACEAE

Scleranthus diander R.Br. (Knawel)

FABACEAE

Pultenaea prostrata Benth. ex Hook.f. (Bush Pea)

GOODENIACEAE

Velleia paradoxa R.Br. (Spur Velleia)

Taxa of flora which are rare

ASTERACEAE

Calocephalus lacteus Less. (Milky Beauty-heads)

Craspedia sp. (Tunbridge) (Billy Buttons)

Vittadinia cuneata DC. (New Holland daisy)

$V$ gracilis (Hook.f.) N.Burb. (New Holland daisy)

$V$. muelleri N.Burb. (Narrow-leaf New Holland daisy)

CONVOLVULACEAE

Wilsonia rotundifolia Hook. (Round-leaf Wilsonia)

POACEAE

Agrostis aemula R.Br. var. aemula (Blown Grass)

Stipa nodosa S.T. Blake (Spear Grass)

* According to Schedules 3 to 5 of the Threatened Species Protection Act 1995 (Tasmania). $\mathrm{E}$ = nationally endangered species, $\mathrm{EN}=$ endemic to Tasmania (Flora Advisory Committee 1994). 
TABLE 4

Summary of principal influences and species richness for the five floristic groups*

\begin{tabular}{llllllll}
\hline Group & Geology & A horizon & $\mathrm{pH}^{\dagger}$ & Slope $^{\dagger}$ & Aspect & $\begin{array}{c}\text { Native species } \\
\text { richness }^{\dagger}\end{array}$ & $\begin{array}{c}\text { Exotic species } \\
\text { richness }^{\dagger}\end{array}$ \\
\hline 1 & Sandstone & Heavy black clay & 9.5 & 0.5 & $\mathrm{~N}-\mathrm{E}$ & $3.8 \pm 1.3$ & $3.2 \pm 2.7$ \\
2 & Sandstone & Heavy black clay & 9.5 & Flat & & 5.0 & 6.0 \\
3 & Dolerite & Medium brown clay & 6.1 & 2.3 & $\mathrm{~N}-\mathrm{E}$ & $6.2 \pm 4.8$ & $14.0 \pm 4.2$ \\
4 & Sandstone & Heavy black clay & 6.9 & 1.7 & $\mathrm{~S}-\mathrm{E}$ & $17.5 \pm 3.1$ & $6.6 \pm 1.8$ \\
5 & Dolerite & Medium brown clay & 6.7 & 5.5 & $\mathrm{~N}-\mathrm{E}-\mathrm{S}$ & $19.6 \pm 4.5$ & $6.9 \pm 4.4$ \\
\hline
\end{tabular}

* Determined using TWINSPAN.

$\dagger$ Mean and standard deviation.

Floristic Group 2 Calocephalus lacteus open grassland $(\mathrm{n}=1)$ Native grasses: Danthonia tenuior, Puccinellia stricta Native forbs: Calocephalus lacteus, Selliera radicans, Asperula conferta

Exotic grasses: Hordeum marinum, Lolium perenne

Exotic forbs: Leontodon taraxacoides, Plantago coronopus, Trifolium dubium, Scorznera laciniata

The vegetation in this quadrat represents a distinct floristic group and is located near the lake edge. It consists of Calocephalus lacteus interspersed with patches dominated by Danthonia tenuior with a range of exotic and native grass and forb species. The soil consists of a black cracking clay A horizon ( $\mathrm{pH} 9$ ), over brown clay B horizon overlying sandstone, and the ground is flat.

Floristic group 3 Lolium perenne-Plantago lanceolata open grassland $(\mathrm{n}=6)$

Native grasses: Danthonia tenuior, Stipa nodosa

Narive forbs: Asperula conferta var. conferta

Exotic grasses: Lolium perenne, Bromus hordeaceus, Bromus diandrus, Cynosurus echinatus, Poa bulbosa

Exotic forbs: Plantago lanceolata, Cirsium vulgare, Tragopogon porrifolius, Trifolium dubium, Hypochoeris radicata

Quadrats in this group are from areas that had been mechanically disturbed or had been subject to refuse dumping. The vegetation is a dense sward, dominated by Lolium perenne and the annual exotic grasses Bromus hordeaceus, $B$. diandrus and Cynosurus echinatus, with native grasses and exotic forbs subdominant. Soils are dark-brown clay loam A horizons with evidence of rubbish dumping or mechanical disturbance over dark-brown to black medium clay B horizons. Slopes are less than $3^{\circ}$ and aspects are north to northeast. The vegetation is variable and appears to be related to the type of disturbance and time since last disturbance.

Floristic group 4 Poa labillardierei-Dichondra repens tussock grassland $(\mathrm{n}=11)$

Native grasses: Poa labillardierei, Themeda triandra, Danthonia tenuior, Elymus scaber

Native forbs: Dichondra repens, Plantago varia, Pimelea humilis, Asperula conferta var. conferta, Geranium solanderi, Vittadinia muelleri, Acaena echinata, Convolvulus erubescens Exotic grasses: Cynosurus echinatus

Exotic forbs: Plantago lanceolata, Hypochoeris radicata, Centaurium erythraea

The vegetation in this group is dominated by Poa labillardierei with Themeda triandra as a subdominant.
In areas subject to regular trampling and compaction by sheep and vehicles, Danthonia tenuior is dominant. A large diversity of native and exotic intertussock forbs and graminoids exist. This group is found to the east and at low height above the lake on soils with heavy black clay A horizons over brown clay B horizons which overlay sandstone. In contrast to floristic groups 1 and 2, $\mathrm{pH}$ is near neutral. Slopes are less than $3^{\circ}$ and aspects are variable. This is community Poa labillardierei-Dichondra repens tussock grassland (Pld) of Kirkpatrick et al. (1988).

Floristic group 5 Eucalyptus viminalis/E. ovata/E. paucifloraConvolvulus erubescens grassy woodland $(n=14)$

Native grasses and graminoids: Themeda triandra, Schoenus absconditus, Danthonia tenuior, Poa rodwayi

Native forbs: Geranium solanderi, Chrysocephalum apiculatum, Pimelea humilis, Oxalis perennans, Scleranthus diander, Plantago varia, Asperula conferta var. conferta

Exotic grasses: Aira caryophyllea, Poa bulbosa

Exotic forbs: Centaurium erythraea, Hypochoeris radicata

This plant community is widespread in the nature reserve and adjacent native pastures. It is dominated by Themeda triandra, with a large diversity of other native species in the intertussock spaces. Poa rodwayi is subdominant. E. pauciflora is present in the adjacent woodland on private land but is absent from the nature reserve. As with floristic group 3, the soils of quadrats in this group have darkbrown clay loam A horizons over dark-brown to black medium clay B horizons, but evidence of mechanical disturbance is absent. This floristic group is not found on sandstone. The slopes are $0^{\circ}$ to $100^{\circ}$ and the aspects north to east. This community corresponds to Eucalyptus viminalis/ E. ovatalE. pauciflora-Convolvulus erubescens grassy woodland (Evc) of Kirkpatrick et al. (1988).

Exotic species richness is high, both at low elevation near the lake and in areas where rubbish dumping has occurred. At low elevation, exotic species richness is associated with high soil moisture and bare ground, and exotic species include Hordeum murinum, Plantago coronopus and Poa bulbosa (fig. 3). Areas of past rubbish-dumping and mechanical disturbance are associated with low bare ground and low native species richness. Abundant exotic species include Plantago lanceolata, Poa bulbosa and Cynosurus echinatus (fig. 3). Hypochoeris radicata, Aira caryophylla and Briza minor are ubiquitous in the reserve. 


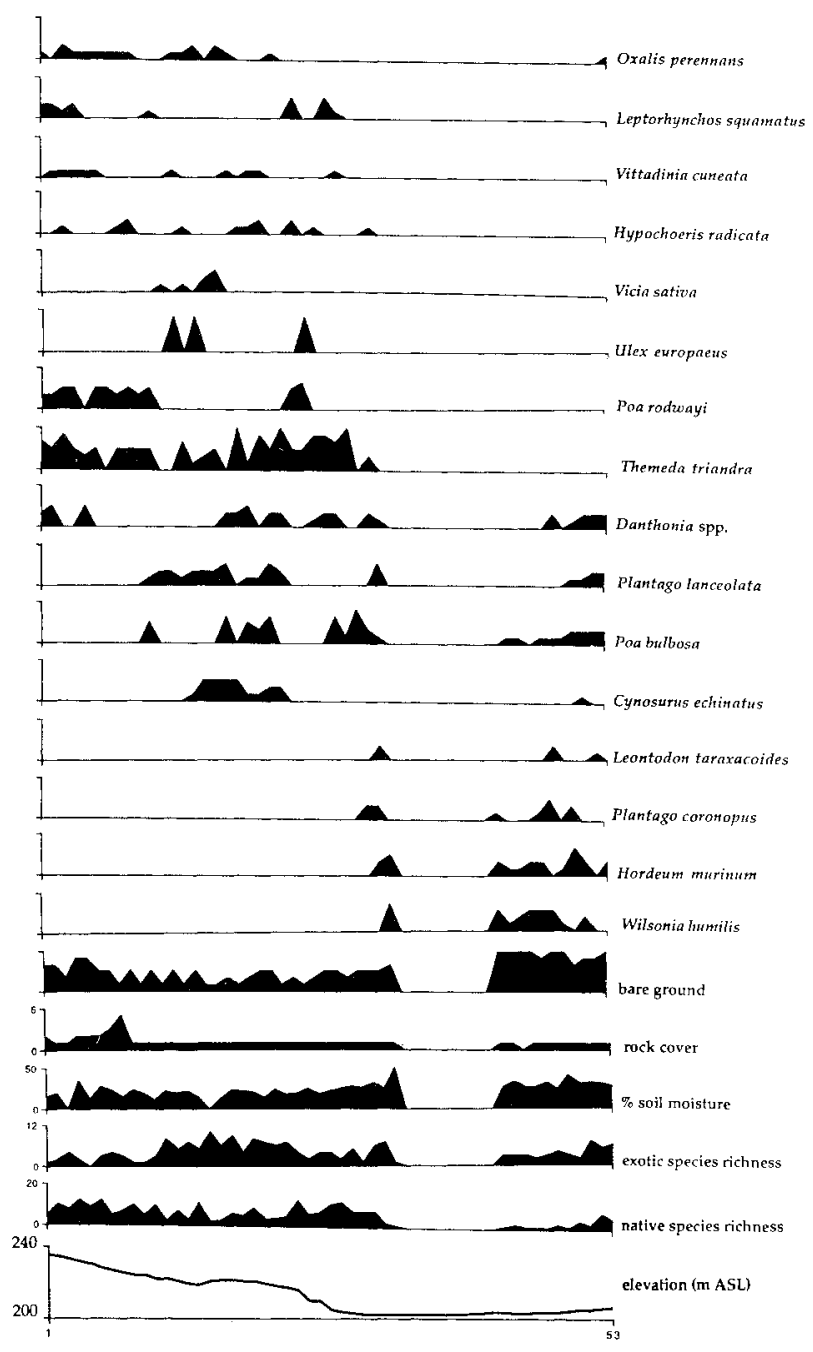

$F I G .3-$ Braun-Blanquet cover of plant species in more than $40 \%$ of the quadrats (Mueller-Dombois \& Ellenberg 1974), percentage cover of bare ground and rock, percentage soil moisture, exotic and native species richness, and the elevation recorded along a transect at Township Lagoon Nature reserve.

\section{Recovery Following Fire}

The recovery from fire by Themeda triandra tussock grassland at Tunbridge, following a spring burn, was rapid. Vegetation recovery following fire was rapid, with fuel loads reaching 5 tonnes/ha after one year, the majority of which was T. triandra (fig. 4). T. triandra always dominated thebiomass, ranging from $63 \%$ to $91 \%$. There was lictle change in the floristic composition of the study site pre- and post-fire. Only two species, the orchid Pterostylis commutata and the daisy Leucochrysum albicans var. tricolor, were seen post-fire that had not been previously recorded. The percentage cover of most species post-fire remained at similar levels to prefire, with the dominant perennial grass $T$. triandra resuming $75-100 \%$ cover immediately post-fire. The relationship between shoot biomass and time in Themeda grassland has been shown to be curvilinear, with the rate of biomass increase reaching almost zero by five years (Groves 1974). This research supports other findings indicating that a fire interval of 2-3 years is most appropriate for this vegetation type for fuel reduction (McDougall 1989).

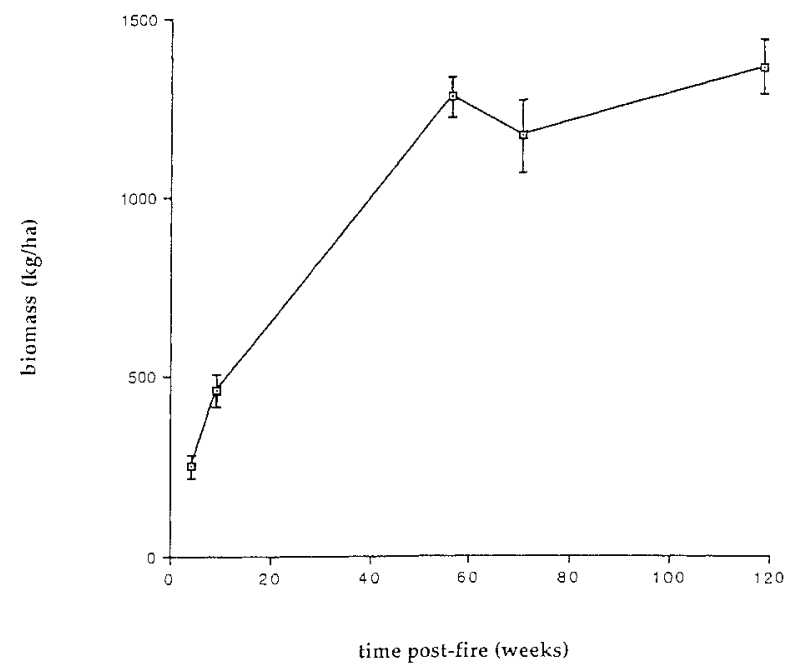

FIG. 4-Rate of growth of Themeda triandra following fire. Mean and standard error of biomass is shown.

\section{DISCUSSION}

The diverse vegetation of the reserve can be explained by environmental factors including geology and soils, $\mathrm{pH}$ and drainage, and by the broad-scale and localised history of mechanical disturbance and rubbish dumping. The importance of the reserve for endangered, vulnerable and rare species, the abundance of exotic species, and the current uses of the reserve by the local community require consideration in management. Active conservation management is essential to maintaining the condition of the reserve. It needs to be favourable to the continued existence of the threatened species, while promoting normal ecosystem processes and preventing threatening processes from taking place.

Creation of a mosaic of different ages by doing small patch burns is desirable, when the overall area of vegetation is small $(<10 \mathrm{ha})$. These need to be undertaken at different times of the year. The escape of fires from the refuse site, however, is impossible to predict. The biomass of Themeda recovers quickly following fire, with the greatest rate of shoot growth occurring within 12 months of the fire. It is an effective form of biomass reduction. It is important that some areas are left unburned, if possible. One patch that has not been burned for at least a decade is currently the focus of soil seed bank and invertebrate studies. The area has traditionally been used as a "common" area for sheep grazing, and there is no indication that occasional light grazing is detrimental to the grassland.

Weed invasion, especially by gorse (Ulex europaeus), is one of the processes which most seriously threatens the long-term viability of this small reserve. In the old tip site, research has shown that weeding techniques, such as topsoil stripping, application of herbicides and burning, can reduce exotic species and favour native species, if used with an understanding of the ecology of the species (Zacharek 1997). Restoration of native vegetation in the larger areas of exotic invasion requires more research. Vehicle access continues to be a problem, with recreational use of the dried-up bed of the salt lake. Access to the grassy areas is leading to soil compaction and subsequent weed invasion. 
A conservation introduction of the Tunbridge buttercup Ranunculus prasinus, to the nature reserve has been successfully completed (Gilfedder et al. 1997, and the site is suitable for other grassland introductions of rare and threatened species, subject to appropriate guidelines (ANPC 1997). The re-introduction of the weeping dryland form of cabbage gum (Eucalyptus pauciflora) is also a management option. It does not currently occur in the reserve, but is in adjacent paddocks, where sheep-grazing has reduced the competition from grasses and allowed the establishment of seedlings.

\section{Rare and Threatened Species}

The reserve is important for the conservation of rare and threatened flora and fauna. Six endangered species, including four endangered at the national level, two vulnerable species, and eight rare species were recorded, six of which were daisies. Management needs to be primarily concerned with the maintenance of these species.

The rubble peppercress (Lepidium hyssopifolium), once extending in its distribution from the South Australian border to northern New South Wales, is now endangered throughout its range in southeastern Australia. It is a member of the Brassicaceae family and was thought to be extinct on the Australian mainland (Leigh et al. 1984) until the mid-1980s, when six small populations were located in Victoria (Cropper 1987). By 1990, only two populations remained in Victoria (Scarlett \& Parsons 1991). In Tasmania, only one population was known by 1990 , and a previously recorded population (Leigh et al. 1984) had disappeared. Thirty extant populations have been located in the past five years (Gilfedder \& Kirkpatrick 1995a), and the Tunbridge population, represented by only a handful of individuals, represents the only population protected in a secure reserve in Tasmania. It is a perennial species that requires soil disturbance for its regeneration, and it occurs in an area that was previously allocated for refuse disposal. Soil disturbance in this area would lead to an enhancement of the population numbers and would be a practical management option.

The straw daisy, Leucochrysum albicans var. tricolor, also a nationally endangered grassland species, occurs in northwestern Tasmania and the Midlands (Gilfedder \& Kirkpatrick 1994). The population at Tunbridge, which numbers less than 30 individuals, is the only lowland population that is not on private land. Thousands of individuals occur on nearby grazing land and their future is secure at these sites if the current land use continues, for grazing by sheep reduces the competition from the grasses and favours this unpalatable daisy.

The Tunbridge buctercup, Ranunculus prasinus, is an endemic species first collected in 1983 (Menadue \& Crowden 1985). It has a very restricted distribution, limited to four sites in the low rainfall area in the central Midlands. It does not naturally occur at this locality, but was introduced to the edges of the lagoon from three populations within a $10 \mathrm{~km}$ radius of the reserve (Gilfedder $e t$ al. 1997). The aim was to secure a population within a conservation reserve, although the current management at all four wild populations is favourable to its continued existence at these sites. The Tunbridge area is currently a declared drought area, and the fate of the introduced plants is unsure.
Two species await taxonomic studies to determine their status, but both have previously been considered at risk. These are Stackhousia gunnii, which, until recently, was thought to be a Tasmanian grasslands endemic (Curtis \& Morris 1975), but is now one of 13-14 taxa that have been subsumed in a taxonomic revision (Barker 1984) into S. monogyna. In Tasmania, S. gunnii, is highly distinct from $S$. monogyna and is considered an endangered taxon (Gilfedder \& Kirkpatrick 1997). An undescribed species, Craspedia species (Tunbridge), which is thought to be endemic to Tasmania and occurs on basalt soils in low rainfall areas in the central Midlands and the Bothwell district, also occurs at the Township Lagoon Nature Reserve.

The Tunbridge district is in an area where mean annual evaporation equals or exceeds rainfall, resulting in the formation of salt lakes. Township Lagoon is the only closed saline lake on crown land in Tasmania, occurring in one of two small areas of endorheic (permanently saline) lagoons in Tasmania (Tunbridge and northwest of Ross) (Buckney $\&$ Tyler 1976). The floor of the lake is a soft layer of mud overlain by a hard crust of salt, and salt has traditionally been harvested from the shores of this lagoon, and others in the district.

Lowland temperate grasslands are important for the conservation of rare and threatened lizard species in southeastern Australia (Osborne et al. 1995). The recently described glossy tussock skink (Pseudemoia pagenstecheri) occurs in dense Themeda triandra grasslands in the nature reserve. This is one of only a few known locations and the only reserved one (Rounsevell et al. 1996). A moth, previously presumed to be extinct in Tasmania, Chrysolarentia decisaria (Walker), was rediscovered at Township Lagoon. Its last collection was in 1904, and its status in Victoria is uncertain (P. McQuillan, pers. comm.) Also, a rare grasshopper (Brachyxema lobipennis) has been recorded recently at Township Lagoon Nature Reserve (P. McQuillan, pers. comm.). These species are listed by the Invertebrate Advisory Committee (1994).

In summary, the proclamation of the Township Lagoon Nature Reserve has been an important step in grassland conservation in Tasmania It is a site of high botanical and faunal significance, and an important remnant and refuge in an area which is largely improved pasture and crops. Periodic inspection by Parks and Wildlife Service field staff, the involvement of the local community, and the preparation of a management plan which includes prescriptions for the perpetuation of the existing native biota will all be important requirements for the reserve.

\section{ACKNOWLEDGEMENTS}

We gratefully acknowledge the help of Tunbridge residents Wayne, Paul Triffett and Jill Worlden for local knowledge. David Rounsevell identified the lizard species, and Peter McQuillan identified invertebrates. Louise Mendel helped with botanical survey and Dr Guus van der Geer drew the map. LG was funded by the World Wildlife Fund for Nature and Save the Bush Program, and the Grassland Ecology Program of the Endangered Species Program, and AZ received funding from the National Estate Grant Program. 


\section{REFERENCES}

Australian Network for Plant Conservation, 1997 : GUIDELINES FOR THE REINTRODUCTION OF THREATENED SPECIES INTO THE WILD. Australian Network for Plant Conservation, Canberra.

BARKer, W.R., 1984: Stackhousiaceae. In George, A. S. (Ed.): FLORA OF AUSTRALIA. VOL. 22. RHIZOPHORALES TO CELASTRALES. Australian Government Publishing Service, Canberra: 186-199.

Buchanan, A.M., 1995: A CENSUS OF THE VASCULAR PLANTS OF TASMANIA. Tasm. Herb. Occ. Publ. 5.

BuCKNEY, R.T. \& TYLER, P.A., 1976: Chemistry of salt lakes and other waters of the sub-humid regions of Tasmania. Aust. J. Mar. Freshw. Res. 27: 359-366.

Cropper, S., 1987: Ecological notes and suggestions for the conservation of a recently discovered sice of Lepidium hyssopifolium Desv. (Brassicaceae) at Bolwarrah, Victoria, Australia. Biol. Conserv. 41: 269-278.

CURTIS, W.M. \& MORRIS, D.I., 1975: THE STUDENT'S FLORA OF TASMANIA. Part 1. 2nd edn. Government Printer, Hobart, Tasmania.

Davies, J., 1988: LAND SYSTEMS OF TASMANIA. REGION 6: SOUTH, EAST AND MIDLANDS - A RESOURCE CLASSIFICATION SURVEY. Department of Agriculture, Tasmania.

FENSHAM, R.J., 1989: The pre-European vegetation of the Midlands, Tasmania: a floristic and historical analysis of vegetation patterns. J. Biogeogr. 16: 29-45.

FEnSham, R.J. \& KiRKPATRICK, J.B., 1939: The conservation of original vegetation remnants in the Midlands, Tasmania. Pap. Proc. R. Soc. Tasm. 123: 229-246.

Flora ADVISORY COMMITTEE, 1994: NATIVE HIGHER PLANT TAXA WHICH ARE RARE OR THREATENED IN TASMANIA. Edn 1. Species at risk, Tasmania - flora. Parks and Wildlife Service, Tasmania.

Fulton, W., 1976: Appendix II. Fauna of the Tunbridge salt lakes. Inland Fisheries Ann. Rep. 84: 20-24.

GENTILLI, J., 1972: AUSTRALIAN CLIMATIC PATTERNS. Nelson, Melbourne.

Gilfedder, L., 1990. Threatened species from Tasmania's remnant grasslands. Tasforests 2: 129-132.

Gilfedder, L. \& Kirkpatrick, J.B., 1994: Culturally induced raricy? - the past and present distributions of Leucochrysum albicans in Tasmania. Aust. J. Bot. 42: 405-416.

Gilfedder, L. \& Kirkpatrick, J.B., 1995a: Conservation ecology and management of two endangered herbs in the Brassicaceae from Tasmania, Australia. In Gilfedder, L. \& Kirkpatrick, J.B. (Eds): THE CONSERVATION ECOLOGY AND MANAGEMENT OF TEN THREATENED SPECIES OF LOWLAND GRASSY ECOSYSTEMS IN TASMANIA. A report to the Worldwide Fund for Nature, Australia and the Australian Nature Conservation Agency. Department of Geography and Environmental Studies, University of Tasmania.

Gilfedder, L. \& Kirkpatrick, J.B., 1995b: Improving the conservation of vegetation remnants in Tasmania. In Saunders, D., Mattiske, E.M. \& Craig, J.L. (Eds): NATURE CONSERVATION 4: THE ROLE OF NETWORKS. Surrey Beatty \& Sons, Chipping Norton, New South Wales: 613-621.

Gilfedder, L. \& Kirkpatrick, J.B., 1997: Distribution, discurbance tolerance and conservation of Stackhousia gunnii Hook. f. in Tasmania. Aust. J. Bot. (in press).

Gilfedder, L. \& Kirkpatrick, J.B. \& Wells, S. 1997: Short note; the endangered Tunbridge buttercup (Ranunculus prasinus) - its ecology, conservation status and introduction to the Township Lagoon Nature Reserve. Aust. J. Ecol. (in press).
Groves, R.H., 1974: Growth of Themeda australis tussock grassland in response to firing and mowing. CSIRO Australia. Div. Plant Ind. Field Stn Rec. 13: 1-7.

HiLL, M.O., 1979. TWINSPAN: A FORTRAN program for arranging multivariate data in an ordered two-way table by classification of the individual and attributes. Cornell University, New York.

INVERTEBrate ADVISORY COMMITTEe, 1994: INTERIM LIST OF NATIVE INVERTEBRATES WHICH ARE RARE OR THREATENED IN TASMANIA. SPECIES AT RISK, TASMANIA - TASMANIA. Parks and Wildlife Service, Tasmania.

Kirkpatrick, J.B., 1994. Tasmania. In McDougall, K. \& Kirkpatrick, J.B. (Eds): CONSERVATION OF LOWLAND NATIVE GRASSLANDS IN SOUTHEASTERN AUSTRALIA. Worldwide Fund for Nature, Sydney: 129-157.

Kirkpátrick, J.B., Gilfedder, L. \& Fensham, R.J., 1988: CITY PARKS AND CEMETERIES: TASMANIA'S REMNANT GRASSLANDS AND GRASSY WOODLANDS. Tasmanian Conservation Trust, Hobart, Tasmania.

Kirkpatrick, J.B., Gilfedder, L., Duncan, F. \& Harris, S., 1991 a: Reservation status and priorities for Tasmanian plants 1. Angiospermae (Dicotyledonae). In Banks M.R. et al. (Eds): ASPECTS OF TASMANIAN BOTANY $-A$ TRIBUTE TO WINIFRED CURTIS. Royal Society of Tasmania, Hobart: 163-172.

Kirkpatrick, J.B., Gilfedder, L., Hickie, J. \& Harris, S., I 991 b: Reservation and conservation status of Tasmanian native higher plants. Wildl. Div. Sci. Rep. 91/2.

Leigh, J.H., BODEN, R. \& BRIGGS, J., 1984: EXTINCT AND ENDANGERED PLANTS OF AUSTRALIA. Macmillan, Melbourne.

MCDOUgall, K.L., 1989: The re-establishment of Themeda triandra (Kangaroo Grass): Implications for the Restoration of Grassland. Arthur Rylah Inst. Environ. Res. Tech. Rep. Ser. 89. Department of Forests, Conservation and Lands, Victoria.

Menadue, Y. \& Crowden, R.K., 1985: Three new species of Ranunculus (Ranunculaceae) from Tasmania. Brunonia 8: $375-380$.

Mueller-Dombois, D. \& EllenberG, H., 1974: AIMS AND METHODS OF VEGETATION ECOLOGY. John Wiley \& Sons, New York.

Osborne, W.S., Kukolic, K. \& Jones, S., 1995: Management of threatened vertebrates in native grasslands: a case of grasping at straws? In Sharp, S. \& Rehwinkel, R. (Eds): MANAGEMENT OF RELICT LOWLAND GRASSLANDS. ACT Parks and Conservation Service, Canberra: 89-96.

RAYMENT, G. E. \& HIGGINSON, F.R., 1992: AUSTRALIAN LABORATORY HANDBOOK OF SOIL AND WATER METHODS. Inkata Press, Melbourne.

Rounsevell, D., Brereton, R. \& Hutchinson M., 1996: The reptiles of Northeast Tasmania, with new records and a key to species of grass skinks Genus Pseudemoia. Rec. Queen Vic. Mus. Art Gallery 103: 193-199.

SCARlett, N.H. \& ParSONS, R.F., 1991: Conservation of Victorian grassland species. In Butler G., Meredith, L. \& Richardson, M. (Eds): CONSERVATION OF RARE AND THREATENED PLANTS IN AUSTRALASIA. Proceedings of the Conference: Protective Custody? - ex situ plant conservation in Australasia. Hobart, March 1996. ANBG \& ANPWS, Canberra: 107-112.

ZACHAREK, A.R., 1997: Management and restoration of native grassy woodland in the Midlands of Tasmania. Unpubl. PhD thesis, Univ. Tasm., Hobart.

(accepted 12 November 1996) 


\begin{abstract}
APPENDIX 1
List of vascular plants recorded at Township Lagoon Nature Reserve.

Species nomenclature follows Buchanan (1995).

(I) following species name $=$ introduced taxa; $(\mathrm{E})=$ taxa endemic to Tasmania.
\end{abstract}

\section{DICOTYLEDONS}

AMARANTHACEAF.

Ptilotus spathulatus (Pussy Tails)

APIACEAE

Apium prostratum (Sea Celery)

Daucus glochidiatus (Austral Carrot)

Lilacopsis polyantha (Creeping Crantzia)

Trachymene humilis

ASTERACEAE

Bellis perennis (English Daisy) (I)

Brachyscome aculeata (Field Daisy)

$B$. rigidula (Hairy Cutleaf Daisy)

Calocephalus lacteus (Milky Beauty-heads)

Chrysocephalum apiculatum (Common Everlasting)

C. semipapposum (Clustered Everlasting)

Cirsium vulgare (Spear Thistle) (I)

Cotula coronopifolia (Water Buttons) (I)

Craspedia sp. (Tunbridge) (Billy Buttons) (E)

Hypochoeris glabra (Smooth Cat's Ear) (I)

H. radicata (Flatweed, Cat's Ear) (I)

Isoetopsis graminfolia (Grass Daisy)

Leontodon taraxacoides (Hawkbit) (I)

Leptorhynchos squamatus (Scaly Buttons)

Leucochrysum albicans var. tricolor (Hoary Sunray)

Microseris lanceolata (Native Dandelion)

Podolepis jaceoides (Showy Podolepis)

Scorznera laciniata (Viper's Grass) (I)

Senecio quadridentatus (Fireweed)

Silybum marianum (Milk Thistle) (I)

Solenogyne dominii (Solenogyne)

S. gunnii (Solenogyne)

Sonchus asper (Prickly Sow Thistle) (I)

S. oleraceus (Sow Thistle) (I)

Taraxacum officinale (Dandelion) (I)

Tragopogon porrifolius (Salsify) (I)

Vittadinia cuneata (New Holland Daisy)

$V$ gracilis (New Holland Daisy)

V. muelleri (New Holland Daisy)

BORAGINACEAE

Cynoglossum suaveolens (Hound's Tooth)

Echium vulgare (Patersons Curse) (I)

Myosotis discolor (Forget-me-not) (I)

BRASSICACEAE

Brassica rapa (Wild Tumip) (I)

Capsella bursa-pastoris (Shepherd's Purse) (I)

Cardaria draba (White Weed) (I)

Erophila verna (Whitlow Grass) (I)

Lepidium hyssopifolium (Peppercress)

Rapistrum rugosum (Turnip Weed) (I)

CAMPANULACEAE

Wahlenbergia stricta (Bluebell)

CARYOPHYLLACEAF

Cerastium glomeratum (Sticky Mouse-eared Chickweed) (I)

Moenchia erecta (I)

Petrorhagia nanteuilii (Childing Pink) (I)

Scleranthus biflorus (Knawel)

$S$ diander (Knawel)

Silene gallica (French Catchfly) (I)

Spergularia media (Coast Sandspurrey) (I)

\section{CHENOPODIACEAE}

Einadia nutans subsp. nutans (Climbing Saltbush)

CLUSIACEAE

Hypericum gramineum (Small St John's Wort)

CONVOLVULACEAE

Convolvulus erubescens (Native Bindweed)

Dichondra repens (Kidney-weed)

Wilsonia rotundifolia (Round-leaf Wilsonia)

CRASSULACEAE

Crassula sieberana (Austral Stonecrop)

DILLENIACEAE

Hibbertia riparia (Guinea Flower)

H. serpyllifolia (Guinea Flower)

DROSERACEAE

Drosera peltata subsp. peltata (Sundew)

EPACRIDACEAE

Acrotriche serrulata (Ants Delight)

Astroloma humifusum (Native Cranberry)

Lissanthe strigosa (Peach Berry)

EUPHORBIACEAE

Poranthera microphylla (Small-leaf Poranthera)

FABACEAE (LEGUMINOSAE)

Bossiaea prostrata (Creeping Bossiaea)

$B$. riparia (Leafless Bossiaea)

Daviesia ulicifolia (Native Gorse)

Medicago lupulina (Black Medic) (I)

Medicago polymorpha (Burr Medic) (I)

Pultenaea prostrata (Dwarf Bush Pea)

Trifolium dubium (Yellow Suckling Clover) (I)

T. glomeratum (Clustered Clover) (I)

T. repens (White Clover, Dutch Clover) (I)

T. striatum (Knotted Clover) (I)

T. subterraneum (Subterranean Clover) (I)

Ulex europaeus (Gorse, Furze) (I)

Vicia sativa (Common Vetch) (I)

FUMARIACEAE

Fumaria sp. (Fumitory) (I)

GENTIANACEAE

Centaurium erythraea (Pink Centaury) (I)

Cicendia filiformis (Slender Cicendia) (I)

GERANIACEAE

Erodium botrys (Long Storks Bill) (I)

E. cicutarium (Common Storksbill) (I)

E. moschatum (Musk Storksbill)(I)

Geranium potentilloides (Geranium)

G. solanderi (Geranium)

Pelargonium australe (Austral Storksbill)

GOODENIACEAE

Goodenia lanata (Native Primrose)

Selliera radicans (Swamp Weed)

Velleia paradoxa (Spur Velleia)

HALORAGACEAE

Gonocarpus tetragynus (Common Raspwort)

LAMIACEAE

Marrubium vulgare (Horehound) (I)

LINACEAE

Linum marginale (Native Flax)

MIMOSACEAE

Acacia dealbata (Silver Wattle) 
